\title{
The Impact of Board Personality Characteristics on Capital Structure of Companies in Iran
}

\author{
Alireza Ghader \\ Psychology Department, Ferdowsi University of Mashhad, Mashhad, Iran \\ Email: Arghadeir44@yahoo.com \\ Saied Namazi Bigi
}

Msc. in Accounting, Nyshabour Branch, Islamic Azad University, Iran

\section{Doi:10.5901/mjss.2015.v6n4s1p388}

\begin{abstract}
In this study, using the five-factor characteristics, the degree of managers' each personal characteristic factor is determined and then, considering the financial data of their attributed companies, the existing relationship between the variables, the sample of the study includes 48 listed companies managers in Iran during 2010-2012. The results revealed that the managers' extrovert and neurosis personage has a meaningful reverse relationship and their agreement, conscientiousness and experience- accepting character has a meaningful direct relationship with the capital structure of companies. The innovative aspect of this paper lies in using on-line questionnaire through creating private hosts and domains for ease of top managers' participation, and also in using reliable questionnaire for converting personality qualitative components into quantitative numbers and figures and making relationships with financial statement data of bourse companies.
\end{abstract}

Keywords: Capital Structure, NEO 5-factor questionnaire, Extrovert, Agreement, Openness to experience, Neurosis, Conscientiousness

\section{Introduction}

Over past half decade, two paradigms of rational behavior of economic agents and the Efficient Markets Theory have been the infrastructure of modern financial assumptions and regnant in majority of financial researches. But, the emergence of some market exceptions which are not definable by the common models of Efficient Market Theories, paved the way for the appearance of some hypotheses as financial-behavioral theories. Financial behavioral theory includes a widespread part of psychological aspects and sociological sciences which are in contradict with Efficient Market Theory. This delicate issue in researching view made the scientists and financial professionals try to survey the financial behavior of companies based on such defaults as investors' irrational behavior, social and cultural effects of behavior on investors. These elements within researches caused the modern financial hypothesis recognizes the importance of human factors effect on financial decision-making in companies. As a result, the companies which according to predicting components of the capital structure are apparently similar, most often choose very different financial fulcrums. This issue propelled the researchers, in their new studies, toward the important effect of individual characteristics of top people (as the executive managers and bosses) on the Capital structure related decisions within companies. Of course, one should be aware of the important role of the financial elements which predict the capital structure. Personage is an extended domain, because it is a complex issue and has various dimensions and facets itself. Since past times, there were enormous efforts to know human personality; some impractical, some superstitious and a few are scientific and reliable. In public speaking, personage has some other meanings. For example, when they say somebody is "personable", it means that s/he possess characteristics that make her/him able to influence others or has a special sobriety and dignity. In contrast to that "depersonalized" means having negative features. Also, the word Personage in practice and custom is used for famous figures that have competence in such realms as politics, science and art. So, the main objective of the current study is to evaluate the board member characteristics on capital structure of listed companies in Tehran Stock exchange.

\section{Theoretical Issues}

The definition of Personality, like most human-related concepts, is not an easy task because the meaning which 
psychologists have provided is so different. From terminology viewpoint, the word is equivalent of English word personality or French word Personalite. It is derived originally from the Latin root persona which means a mask that the theatre actors wore in ancient Greece and Roam. About individual differences and personage, there have been various viewpoints from past times to now. But, over past two decades this area was dominant by Robert McCrae and Paul Costa's 5-factor model of personality (1987). The result of many surveys using factor analysis and being based on personality features was the introduction of 5 -factor model of personality. One of the most sizeable works in this field is related to two researchers, Robert McCrae and Paul Costa's work. After extended studies, they concluded that despite all existing differences in political, cultural and economic experiences within different countries, there is a same pattern of change in personality traits in all cultures.

McCrae and Costa (1991) formulated a questionnaire for evaluating five personal dimensions and thirty personal traits and offered it as NEO-PIR (NEO Personality Inventory Revised). Although they had prepared this questionnaire in early 1980s which only had assessed three dimensions of Neurosism, extroversion, and openness to experience, but the development of the latter identified two other factors; agreement and conscientiousness. The combination of different financial resources in a company is called Capital Structure (Oxford's Dictionary of Financial and Banking Sciences, 2005). In studying the capital structure of companies it is tried to identify the combination of different financial resources that are used in activities financing and company needed investments (Myers, 2001; Brounen et al., 2006). Also, it can be said that the aim of determining capital structure is specification of financial resources of company in order to maximize its stakeholders' wealth. Based on the Static Parallel Theory, companies demand equilibrium between their profits and the debt release costs which leads to making optimum capital structure of those companies and will optimized firms value. Within this viewpoint, the goal is achieving the optimum debt ratio and it is operated in a way that the real debt ratio will headed up to the optimum debt ratio. Based on the Hierarchical Theory, there is no optimum debt ratio and the companies finance without considering capital structure and use foreign funds only when their internal funds are not enough.

\section{Related Literature}

Kordestani and Najafi (2009) studied the determinant factors of capital structure within the listed firms in Tehran Securities bourse. Considering 93 companies confirmed that profitability is one of the effective factors in capital structure (debt ratio) and based on the Hierarchical Theory there is a negative meaningful relationship between these two variables.

Kanifer et al., (2010) in a shared study declared that managers' personality differences can be the source of creativity development or the root of many organizational problems. The aim of this study was recognizing the managers' personality based on the 5-BIG theory. The results show that the mean of Neurosism rate between managers is below the norm and the mean of four components - conscientiousness, experience acceptance, agreement and extroversion- is above the moderate level.

Eslami Bidgoli and Mazaheri (2010) evaluated the Hierarchical and Static Parallel theories. Based on their observation the Static Parallel theory is applicable to a great extent for capital structure of Iranian firms.

Nasirzade and Mostaghiman (2011) considered two theories of Static Parallel and Hierarchical theory which are capital structure theories. The resulting data reveals that none of these two theories is strictly and completely capable of describing capital structure of companies, but the evidences asserted more endorsement for Static Parallel theory.

Setayesh et al., (2002) considering the relationship between competition in product market and capital structure and using competition indicators, found out a positive meaningful relationship and concluded that the relationship between delayed capital structure with capital structure is positive and meaningful and since the delayed capital structure coefficient is between 0 and 1, so there is dynamic capital structure in Iran.

Lashkari and Mortazi (2002) surveyed the existing relationship between stakeholders' personal traits at the time of purchasing stocks and resulted that the amount of investment accompanied has a direct connection to their selfconfidence and an indirect one with their logic; it means that people do not always perform completely rational.

Mayfield et al., (2008) examined the relationship between cognitive elements and long-term or short-term investment objectives; they mainly focused on 5-BIG classification model and finally introduced and developed this model as a proper applicable method for investigating the economic behavior of people.

Ricciardi (2008) has studied one of the psychological aspects of investor's behavior; risk perception. He came to the conclusion that one's risky behavior could have great effect in their financial and investing areas.

DeAngelo, DeAngelo and Whited (2011) based on a dynamic model of capital structure indifferent industries, asserted that the debt ratio adjusts gradually and approaches to the optimum debt ratio, but it is not a specific and fixed 
ratio.

Malmendier (2011) states that the managers who have a depression experience oppose to debt and mainly rely on internal financing and also the managers with military experiences follow more offensive policies such as increasing financial fulcrums.

\section{The Research Methodology}

The instrument for gathering the needed data in this paper is a questionnaire and surveying some records and evidences of financial statements and also observing the balance sheet information of the accepted firms in Tehran Securities bourse from the beginning of 2009 to the end of 2012.

\subsection{Statistical and Sample Population}

The research sample involves the companies that are selected from the mentioned statistical population based on the following conditions and features:

Companies must be active on the Tehran Stock Exchange during a financial period from 2009 - 2012.

Finance both from stock diffusion and from obtaining debts.

Be not from Holding or financial mediating companies.

Do not change their financial year during the research period.

Their slightly information be available.

Have consent to answer to the personality questionnaire.

According to the mentioned conditions, 48 companies were qualified during the period (from 2010-2012) all of which were selected as the statistical population due to limitations.

Because it the current study the indirect hypotheses are postulated we selected Pearson's correlation as well regression coefficient in order to testing of hypotheses.

\subsection{Research Hypotheses}

Hypothesis 1: There is a meaningful relationship between the managers' extroversion characteristics and capital structure.

Hypothesis 2: There is a meaningful relationship between the managers' agreement characteristics and capital structure.

Hypothesis 3: There is a meaningful relationship between the managers' conscientiousness characteristic and capital structure.

Hypothesis 4: There is a meaningful relationship between the managers' Neurosism characteristic and capital structure.

Hypothesis 5: There is a meaningful relationship between the managers' openness to experiences characteristic and capital structure.

Hypothesis 6: There is a meaningful relationship between the managers' personal characteristics and capital structure.

\subsection{Data Analysis}

The statistical data analysis method is influenced by research methodology and since the present research method is a descriptive and correlated kind, so the Regression Analyses are used. Regression analysis is one of the most important methods of statistical analyses which is used to a great extent in estimation and prediction of the relationships between the variables. It usually applies to determine the dependency level of two or more variables; dependent variable and independent variable(s). 
Table 1. Variables measurement

\begin{tabular}{|l|l|l|l|}
\hline Variable & Formula & Data & Source \\
\hline Capital Structure & Debt/asset & Debt/asset book value & Balance sheet \\
\hline Assets Output Rate & Profit/ asset (ROA) & Net profit, total asset & Profit and loss, balance sheet \\
\hline Company Size & Total assets logarithm & Sum of total asset & Balance sheet \\
\hline $\begin{array}{l}\text { Sales Growth Rate } \\
\text { Personality }\end{array}$ & Period sale- last year sale & Period sales & Profit and loss \\
Variables & $\begin{array}{l}\text { NEO and Rogers' 5-factor } \\
\text { model }\end{array}$ & $\begin{array}{l}\text { Resulted scores of the standard } \\
\text { questionnaire }\end{array}$ & $\begin{array}{l}\text { Bosses and financial } \\
\text { managers }\end{array}$ \\
\hline
\end{tabular}

The resulting data of this research from frequency distribution of marital statues shows that from 85 subjects, 3 (3.5\%) are single and $82(96.5 \%)$ are married. The frequency distribution of age among the studied population reveals that from 85 subjects, 1 person (1.2\%) are below 20 to 30 years old, $15(17.6 \%)$ are 31 to 40 years old, $30(35.3 \%)$ are 41 to 50 and $39(45.9 \%)$ are over 50 . The frequency distribution of the education level among the target population shows that from 85 subjects, $52(61.2 \%)$ are B.A. $31(36.6 \%)$ are M.A. and $2(2.4 \%)$ are Ph.D. The frequency distribution of the organizational position shows that from 85 subjects, $43(50.6 \%)$ are bosses and $42(49.4 \%)$ are financial managers.

Table 2. Descriptive statistics of questionnaire data

\begin{tabular}{|c|c|c|c|c|c|}
\hline Gender & Frequency & Percentage & Marital state & Frequency & Percentage \\
\hline Male & 83 & 97.6 & Single & 3 & 3.5 \\
\hline Female & 2 & 2.4 & Married & 82 & 96.5 \\
\hline Total number & 85 & 100 & Total number & 85 & 100 \\
\hline Education level & Frequency & Percentage & Income level & Frequency & Percentage \\
\hline B.A & 52 & 61.2 & No answer & 79 & 92.9 \\
\hline M.A & 31 & 36.5 & $12000000 \mathrm{R}$ & 1 & 1.2 \\
\hline P.H.D & 2 & 2.4 & $15000000 \mathrm{R}$ & 2 & 2.4 \\
\hline Total number & 85 & 100 & $4000000 \mathrm{R}$ & 1 & 1.2 \\
\hline General health level & Frequency & Percentage & $5000000 \mathrm{R}$ & 1 & 1.2 \\
\hline $\mathbf{2}$ & 3 & 3.5 & $3500000 \mathrm{R}$ & 1 & 1.2 \\
\hline $\mathbf{4}$ & 9 & 10.6 & Total number & 85 & 100 \\
\hline $\mathbf{5}$ & 30 & 35.3 & Work years & Frequency & Percentage \\
\hline $\mathbf{6}$ & 27 & 31.8 & Below 5 years & 4 & 4.7 \\
\hline $\mathbf{7}$ & 16 & 18.8 & $6-10$ years & 10 & 11.8 \\
\hline Total number & 85 & 100 & $11-15$ years & 18 & 21.2 \\
\hline Great & Frequency & Percentage & $16-20$ years & 14 & 16.5 \\
\hline Good & 14 & 16.5 & Over 20 years & 39 & 45.9 \\
\hline Average & 49 & 57.6 & Total number & 85 & 100 \\
\hline Total number & 22 & 25.9 & Age & Frequency & Percentage \\
\hline Organizational position & Frequency & Percentage & $31-40$ & 1 & 1.2 \\
\hline Manager & 43 & 50.6 & $41-50$ & 30 & 17.6 \\
\hline Financial manager & 42 & 49.4 & Over 50 & 39 & 45.9 \\
\hline Economber & 85 & 100 & Total number & 85 & 100 \\
\hline
\end{tabular}

\subsection{Normality test of data by Kolmogref-Smirnof (K-S) Test}

For implementing the statistics techniques, first it should be determined whether the gathered data have normal or abnormal distribution. If the collected data for hypotheses testing is normal, parametric tests are applicable and in case of being abnormal the nonparametric tests could be used. For this purpose, in this phase the resulted information of K-S test about each dependent and independent variables is considered and based on results, the proper tests for examining the accuracy and correctness of hypotheses are selected.

$\mathrm{H}_{0}$ : The data for variable i have normal distribution.

$\mathrm{H}_{1}$ : The data for variable i have not normal distribution. 
Based on the results in the following table, if the amount of a meaningful level is bigger than the error amount, the $\mathrm{H}_{0}$ and if the amount of a meaningful level is smaller than the error amount, the $\mathrm{H}_{1}$ is concluded.

Table 3. The result of testing independent variables

\begin{tabular}{|l|c|c|c|c|c|}
\hline Factor & Statistic Z & Meaningful level & Error amount & Hypothesis confirmation & Results \\
\hline Extroversion & 0.541 & 0.548 & 0.05 & $\mathrm{H}_{0}$ & normal \\
\hline Agreement & 0.621 & 0.447 & 0.05 & $\mathrm{H}_{0}$ & normal \\
\hline Conscientiousness & 0.824 & 0.328 & 0.05 & $\mathrm{H}_{0}$ & normal \\
\hline Neurosism & 0.215 & 0.798 & 0.05 & $\mathrm{H}_{0}$ & normal \\
\hline Openness to Experience & 0.325 & 0.651 & 0.05 & $\mathrm{H}_{0}$ & normal \\
\hline Managers' Personality Characteristics & 0.856 & 0.348 & 0.05 & $\mathrm{H}_{0}$ & normal \\
\hline Financial Fulcrum (Capital Structure) & 0.987 & 0.097 & 0.05 & $\mathrm{H}_{0}$ & normal \\
\hline
\end{tabular}

According to the results of the above table, since the amount of meaningful level for all components is bigger than error amount 0.05 , these variables have normal distribution and to test the hypotheses, parametric tests are used.

\subsection{The Research Variables}

The state of managers' personality characteristics and five big personality factors within the accepted firms in Tehran Securities bourse are shown in Table 3 as well.

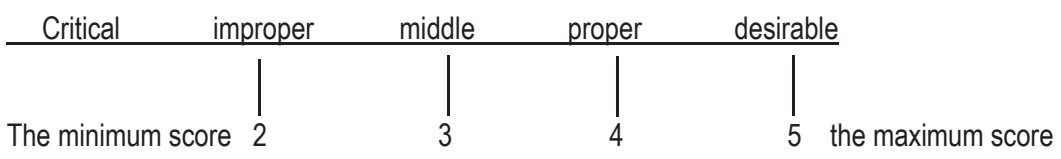

Table 4. The mean test of the statistic population $\left(\mathrm{H}_{0}: \mu=3\right)$

\begin{tabular}{|l|c|c|c|c|c|c|c|}
\hline Variable & Mean & $\begin{array}{c}\text { Standard } \\
\text { deviation }\end{array}$ & $\begin{array}{c}\text { Statistic } \\
\text { T }\end{array}$ & $\begin{array}{c}\text { Meaningful } \\
\text { number }\end{array}$ & $\begin{array}{c}\text { Low } \\
\text { level }\end{array}$ & $\begin{array}{c}\text { High } \\
\text { level }\end{array}$ & $\begin{array}{c}\text { Variable } \\
\text { condition }\end{array}$ \\
\hline Managers' Personality Characteristics & 3.3542 & 0.28796 & 11.342 & 0.00 & 0.2921 & 0.4164 & proper \\
\hline Extroversion & 3.4824 & 0.50430 & 8.818 & 0.00 & 0.3736 & 0.5911 & high \\
\hline Agreement & 2.3304 & 0.32668 & -18.898 & 0.00 & -0.7401 & -0.5991 & low \\
\hline Conscientiousness & 3.1578 & 0.30348 & 4.795 & 0.00 & 0.0924 & 0.2233 & high \\
\hline Neurosism & 2.7755 & 0.47941 & -4.318 & 0.00 & -0.3297 & -0.1211 & Low(proper) \\
\hline Openness to Experience & 1.8569 & 0.29564 & -34.649 & 0.00 & -1.2069 & -1.0794 & low \\
\hline
\end{tabular}

\subsection{Stability of Variances}

One of the other hypotheses in analysis is the assumption about the stability of variance in the error sentence. If the variance of error has not a fixed sentence that is Heteroskedasticity variance. One of the heteroskedasticity variance diagnosis tests is White and Glejser's Test. In this test the null hypotheses is so: The variance of errors are not stable.

Table 5. Variances stability test according to Glejser's Test

\begin{tabular}{|l|c|c|c|}
\hline F-statistic & 7.915 & Prob.F(4.80) & 0.00 \\
\hline Obs*R-squared & 21.04 & Prob. Chi-Square(4) & 0.00 \\
\hline Scaled explained SS & 21.901 & Prob. Chi-Square(4) & 0.00 \\
\hline
\end{tabular}


Table 6. Variances stability test according to White's Test

\begin{tabular}{|l|c|c|c|}
\hline F-statistic & $\mathbf{1 0 . 6 7 4}$ & Prob.F(4.80) & $\mathbf{0 . 0 3 5}$ \\
\hline Obs*R-squared & 15.520 & Prob. Chi-Square(4) & 0.001 \\
\hline Scaled explained SS & 10.750 & Prob. Chi-Square(4) & 0.016 \\
\hline
\end{tabular}

According to the above table, the achieved amount of Glesjer's statistic is equal to 7.91 and the other result of White Test is 10.67. The amount of a meaningful level resulted from these tests is equal to 0.00 and 0.035 . Since this quantity is smaller than the test meaningful level which is 0.05 , therefore the variance of errors is stable.

\section{Testing of Hypotheses}

\subsection{First Hypothesis}

There is a meaningful relationship between the managers' extroversion characteristics and capital structure.

Table 7. Pearson's correlation coefficient between the first hypothesis variables

\begin{tabular}{|l|l|c|c|c|c|}
\hline \multirow{3}{*}{$\begin{array}{l}\text { Capital } \\
\text { Structure }\end{array}$} & Statistic & extroversion & rate of assets output & quantity & Rate of sales growth \\
\cline { 2 - 6 } & Pearson's correlation & $-0.353^{* *}$ & $0.754^{* *}$ & $0.347^{* *}$ & $0.576^{* *}$ \\
\cline { 2 - 6 } & Meaningful level & 0.001 & 0.000 & 0.001 & 0.000 \\
\cline { 2 - 6 } & number & 85 & 85 & 85 & 85 \\
\hline
\end{tabular}

According to the above table, since the meaningful level for each of the variables with capital structure is smaller than the error amount is 0.05 , so the result is that the $\mathrm{H}_{0}$ is rejected and $\mathrm{H}_{1}$ (the research hypothesis) which asserts the existence of a meaningful relationship between extroversion (EXT), rate of assets output, amount and rate of sales growth and the capital structure is confirmed and the correlation coefficients are equal to $-0.353,0.754,0.347,0.576$.

Table 8. Regression coefficients of the first hypothesis test

\begin{tabular}{|c|c|c|c|}
\hline \multirow{2}{*}{$\begin{array}{l}\text { Explanatory } \\
\text { Variable }\end{array}$} & \multirow{2}{*}{$\begin{array}{c}\text { Dependent variable } \\
\text { coefficient }\end{array}$} & \multicolumn{2}{|c|}{ (Capital structure) } \\
\hline & & Statistic T & $P$ value \\
\hline Fixed Amount & -0.109 & -0.349 & 0.728 \\
\hline Extroversion & -0.364 & 3.062 & 0.002 \\
\hline Rate of Assets Output & 0.728 & 5.700 & 0.000 \\
\hline Amount & 0.006 & 0.362 & 0.718 \\
\hline Rate of sales growth & 0.108 & 2.475 & 0.015 \\
\hline Statistic F & \multicolumn{3}{|c|}{30.026} \\
\hline $\mathrm{P}$-value & \multicolumn{3}{|c|}{0.000} \\
\hline $\mathbf{R}^{2}$ & \multicolumn{3}{|c|}{0.600} \\
\hline Adjusted R² & \multicolumn{3}{|c|}{0.580} \\
\hline Durbin-Watson & \multicolumn{3}{|c|}{2.761} \\
\hline
\end{tabular}

According to coefficient column for capital structure, the regression equation could be as follows:

$\mathrm{DR}=-0.109+(-0.364) \mathrm{EXT}+(0.728) \mathrm{ROA}+(0.006) \mathrm{SIZE}+(0.108) \mathrm{GR}$

Based on Table 8, the coefficient of managers' extroversion characteristic is negative and in level 5 percent is meaningful; this shows that with one unit progression in managers' extroversion characteristic, capital structure will progress up to -0.364 units, so they have a negative reverse relationship. Based on the achieved results, the determining coefficient $\left(R^{2}\right)$ is equal to 0.006 and this quantity shows that 60 percent of capital structure changes can be explained by changes in extroversion characteristic, rate of assets output, the size of company and the rate of sales growth. 


\subsection{Second hypothesis}

There is a meaningful relationship between the managers' agreement characteristics and capital structure.

Table 9. Pearson's correlation coefficient between second hypothesis variables

\begin{tabular}{|l|l|c|c|c|c|}
\hline & Statistic & Agreement & Rate of assets output & size & Rate of sales growth \\
\hline \multirow{3}{*}{$\begin{array}{l}\text { Capital } \\
\text { structure }\end{array}$} & Pearson's coefficient & $0.703^{* *}$ & $0.754^{* *}$ & $0.347^{* *}$ & $0.576^{* *}$ \\
\cline { 2 - 6 } & Meaningful level & 0.000 & 0.000 & 0.001 & 0.000 \\
\cline { 2 - 6 } & number & 85 & 85 & 85 & 85 \\
\hline
\end{tabular}

According to the above table, since a meaningful level for each of the variables in front of the capital structure, is smaller than the error amount 0.05 , so as the result, the null hypothesis is rejected and $\mathrm{H}_{1}$ (research hypothesis) which asserts the existing meaningful relationship between agreement (AGREE), rate of assets output, size and rate of sales growth with capital structure, is confirmed and the correlation coefficient are $0.703,0.754,0.347$ and 0.576 .

Table 10. Regression coefficients of the second hypothesis test

\begin{tabular}{|l|c|c|c|}
\hline \multirow{2}{*}{$\begin{array}{l}\text { Explanatory } \\
\text { Variable }\end{array}$} & $\begin{array}{c}\text { Dependent variable } \\
\text { coefficient }\end{array}$ & (Capital structure) \\
\hline Fixed Amount & -0.484 & -1.835 & P value \\
\hline Agreement & -0.847 & 5.487 & 0.070 \\
\hline Rate of Assets Output & 0.426 & 3.912 & 0.000 \\
\hline Amount & 0.009 & 0.666 & 0.000 \\
\hline Rate of Sales Growth & 0.115 & 3.150 & 0.007 \\
\hline Statistic F & \multicolumn{3}{|c|}{} \\
\hline P -value & \multicolumn{3}{|c|}{} \\
\hline $\mathbf{R}^{2}$ & \multicolumn{3}{|c|}{0.851} \\
\hline Adjusted $\mathbf{R}^{2}$ & \multicolumn{3}{|c|}{0.710} \\
\hline Durbin-Watson & \multicolumn{3}{|c|}{0.695} \\
\hline
\end{tabular}

According to coefficient column for capital structure (from 1388 to 1390), the regression equation could be as follows:

$Y=-0.484+(-0.847)$ AGREE + (0.426) ROA + (0.542) SIZE + (0.183) GR

Based on table 10, the coefficient of managers' agreement characteristic is positive and in level 5 percent is meaningful; this shows that with one unit progression in managers' agreement characteristic, capital structure will progress up to 0.847 units so they have a positive direct relationship. Based on the achieved results, the determining coefficient $\left(R^{2}\right)$ is equal to 0.710 and this quantity shows that 71 percent of capital structure changes can be explained by changes in agreement characteristic, rate of assets output, the size of company and the rate of sales growth. Since the quantity of Durbin -Watson is between the standard intervals 1.5 to 2.5 , one could conclude the independence of the remaining quantities. According to the above table, the calculated meaningful level for the statistic $\mathrm{F}$ is smaller than 0.05 and shows the meaningfulness of regression at $95 \%$. Therefore, based on the mentioned indicators, the model has the needed adequacy.

\subsection{Third hypothesis}

There is a meaningful relationship between the managers' conscientiousness characteristic and capital structure.

Table 11. Pearson's correlation coefficient between third hypothesis variables

\begin{tabular}{|l|l|c|c|c|c|}
\hline & Statistic & conscientiousness & Rate of assets output & size & Rate of sales growth \\
\hline \multirow{3}{*}{$\begin{array}{l}\text { Capital } \\
\text { structure }\end{array}$} & Pearson's coefficient & $0.768^{* *}$ & $0.754^{* *}$ & $0.347^{* *}$ & $0.576^{* *}$ \\
\cline { 2 - 6 } & Meaningful level & 0.000 & 0.000 & 0.001 & 0.000 \\
\cline { 2 - 6 } & number & 85 & 85 & 85 & 85 \\
\hline
\end{tabular}


According to the above table, since a meaningful level for each of the variables in front of the capital structure is smaller than the error amount 0.05 , so as the result, the null hypothesis is rejected and $\mathrm{H}_{1}$ (research hypothesis) which asserts the existing meaningful relationship between conscientiousness (CONS), rate of assets output, size and rate of sales growth with capital structure, is confirmed and the correlation coefficient are $0.703,0.754,0.347$ and 0.576 . Also, meaningful relationship between conscientiousness (CONS), rate of assets output, size and rate of sales growth with capital structure is confirmed and the correlation coefficient are $0.553,0.571,0.410$ and 0.628 .

Table 12. Regression coefficients of the third hypothesis test

\begin{tabular}{|l|c|c|c|}
\hline \multirow{2}{*}{$\begin{array}{l}\text { Explanatory } \\
\text { variable }\end{array}$} & Dependent variable & (Capital structure) \\
\cline { 2 - 4 } & Coefficient & Statistic T & P value \\
\hline Fixed Amount & -0.594 & -2.382 & 0.020 \\
\hline Conscientiousness & -0.887 & 6.742 & 0.000 \\
\hline Rate of Assets Output & 0.357 & 3.430 & 0.001 \\
\hline Amount & 0.013 & 1.030 & 0.306 \\
\hline Rate of Sales Growth & 0.103 & 3.005 & 0.004 \\
\hline Statistic F & \multicolumn{3}{|c|}{58.445} \\
\hline P -value & \multicolumn{3}{|c|}{$0.000^{a}$} \\
\hline $\mathbf{R}^{2}$ & \multicolumn{3}{|c|}{0.745} \\
\hline Adjusted $\mathbf{R}^{2}$ & 0.732 \\
\hline Durbin-Watson & \multicolumn{3}{|c|}{1.552} \\
\hline
\end{tabular}

According to coefficient column for capital structure the regression equation could be as follows:

$Y=-0.594+(-0.887)$ CONS + 0.357$) \mathrm{ROA}+(0.013) \mathrm{SIZE}+(0.103) \mathrm{GR}$

Based on Table 12, the coefficient of managers' conscientiousness characteristic is positive and in level 5 percent is meaningful; this shows that with one unit progression in managers' conscientiousness characteristic, capital structure will progress up to 0.887 units, so they have a positive direct relationship. Based on the achieved results, the determining coefficient $\left(R^{2}\right)$ is equal to 0.745 and this quantity shows that 74 percent of capital structure changes can be explained by changes in conscientiousness characteristic, rate of assets output, the size of company and the rate of sales growth. Since the quantity of Durbin - Watson is between the standard intervals 1.5 to 2.5 , one could conclude the independence of the remaining quantities. According to the above table, the calculated meaningful level for the statistic $\mathrm{F}$ is smaller than 0.05 and shows the meaningfulness of regression at $95 \%$. Therefore, based on the mentioned indicators, the model has the needed adequacy.

\subsection{Fourth hypothesis}

There is a meaningful relationship between the managers' Neurosism characteristic and capital structure.

Table 13. Pearson's correlation coefficient between fourth hypothesis variables

\begin{tabular}{|l|l|c|c|c|c|}
\hline & Statistic & neurosis & Rate of assets output & size & Rate of sales growth \\
\hline \multirow{3}{*}{$\begin{array}{l}\text { Capital } \\
\text { structure }\end{array}$} & Pearson's coefficient & $0.354^{* *}$ & $0.754^{* *}$ & $0.347^{* *}$ & $0.576^{* *}$ \\
\cline { 2 - 6 } & Meaningful level & 0.001 & 0.000 & 0.001 & 0.000 \\
\cline { 2 - 6 } & Number & 85 & 85 & 85 & 85 \\
\hline
\end{tabular}

$P<0.05^{*} ; P<0.01^{* *}$

According to the above table, since a meaningful level for each of the variables in front of the capital structure is smaller than the error amount 0.05 , so as the result, the null hypothesis is rejected and $\mathrm{H}_{1}$ (research hypothesis) which asserts the existing meaningful relationship between Neurosism (NEUR), rate of assets output, size and rate of sales growth with capital structure, is confirmed and the correlation coefficient are $-0.354,0.754,0.347$ and 0.576 . 
Table 14. Regression coefficients of the fourth hypothesis test

\begin{tabular}{|c|c|c|c|}
\hline \multirow{2}{*}{$\begin{array}{l}\text { Explanatory } \\
\text { Variable }\end{array}$} & Dependent variable & \multicolumn{2}{|c|}{ (Capital structure) } \\
\hline & coefficient & Statistic T & P-value \\
\hline Fixed Amount & -0.088 & -0.296 & 0.768 \\
\hline Neurosism & -0.285 & -2.547 & 0.005 \\
\hline Rate of Assets Output & 0.686 & 3.430 & 0.000 \\
\hline Amount & 0.008 & 0.463 & 0.645 \\
\hline Rate of Sales Growth & 0.115 & 2.599 & 0.011 \\
\hline Statistic F & \multicolumn{3}{|c|}{58.445} \\
\hline P -value & \multicolumn{3}{|c|}{$0.000^{a}$} \\
\hline $\mathbf{R}^{2}$ & \multicolumn{3}{|c|}{0.745} \\
\hline Adjusted $\mathrm{R}^{2}$ & \multicolumn{3}{|c|}{0.732} \\
\hline Durbin-Watson & \multicolumn{3}{|c|}{1.552} \\
\hline
\end{tabular}

According to coefficient column for capital structure the regression equation could be as follows:

$Y=-0.088+(-0.285) \mathrm{NEUR}+(0.686) \mathrm{ROA}+(0.008) \mathrm{SIZE}+(0.115) \mathrm{GR}$

Based on Table 14, the coefficient of managers' Neurosism characteristic is negative and in level 5 percent is meaningful; this shows that with one unit progression in managers' Neurosism characteristic, capital structure will progress up to 0.887 units so they have a reverse negative relationship. Based on the achieved results, the determining coefficient $\left(R^{2}\right)$ is equal to 0.602 and this quantity shows that 60 percent of capital structure changes can be explained by changes in Neurosism characteristic, rate of assets output, the size of company and the rate of sales growth. Since the quantity of Durbin-Watson is between the standard intervals 1.5 to 2.5 , one could conclude the independence of the remaining quantities. According to the above table, the calculated meaningful level for the statistic $F$ is smaller than 0.05 and shows the meaningfulness of regression at $95 \%$. Therefore, based on the mentioned indicators the model has the needed adequacy.

\subsection{Fifth hypothesis}

There is a meaningful relationship between the managers' openness to experiences characteristic and capital structure.

Table 15. Pearson's correlation coefficient between fifth hypothesis variables

\begin{tabular}{|l|l|c|c|c|c|}
\hline & Statistic & openness to experience & Rate of assets output & size & Rate of sales growth \\
\hline \multirow{3}{*}{$\begin{array}{l}\text { Capital } \\
\text { structure }\end{array}$} & Pearson's coefficient & $0.455^{\star *}$ & $0.754^{* \star}$ & $0.347^{* *}$ & $0.576^{* *}$ \\
\cline { 2 - 6 } & Meaningful level & 0.000 & 0.000 & 0.001 & 0.000 \\
\cline { 2 - 6 } & Number & 85 & 85 & 85 & 85 \\
\hline
\end{tabular}

According to the above table, since a meaningful level for each of the variables in front of the capital structure is smaller than the error amount 0.05 , so as the result, the null hypothesis is rejected and $\mathrm{H}_{1}$ (research hypothesis) which asserts the existing meaningful relationship between openness to experience (OTE), rate of assets output, size and rate of sales growth with capital structure, is confirmed and the correlation coefficient are $-0.455,0.754,0.347$ and 0.576 .

Table 16. Regression coefficients of the fifth hypothesis test

\begin{tabular}{|l|c|c|c|}
\hline \multirow{2}{*}{$\begin{array}{l}\text { Vxplanatory } \\
\text { Variable }\end{array}$} & Dependent variable & (Capital structure) \\
\hline Fixed Amount & -0.174 & Statistic T & P-value \\
\hline Openness to Experience & -0.651 & -0.569 & 0.571 \\
\hline Rate of Assets Output & 0.669 & -6.962 & 0.000 \\
\hline Amount & 0.007 & 5.372 & 0.000 \\
\hline Rate of Sales Growth & 0.111 & 0.415 & 0.680 \\
\hline Statistic F & \multicolumn{3}{|c|}{2.593} \\
\hline P -value & \multicolumn{3}{|c|}{30.602} \\
\hline $\mathbf{R}^{2}$ & \multicolumn{3}{|c|}{0.000} \\
\hline Adjusted R & \multicolumn{3}{|c|}{0.605} \\
\hline Durbin-Watson & 0.585 \\
\hline
\end{tabular}


According to coefficient column for capital structure the regression equation could be as follows:

$Y=-0.174+(0.651)$ OTE $+(0.669)$ ROA + (0.007) SIZE + (0.111) GR

Based on Table 16, the coefficient of managers' openness to experience characteristic is positive and in level 5 percent is meaningful; this shows that with one unit progression in managers' openness to experience characteristic, capital structure will progress up to 0.651 units so they have a direct positive relationship. Based on the achieved results, the determining coefficient $\left(R^{2}\right)$ is equal to 0.605 and this quantity shows that 61 percent of capital structure changes can be explained by changes in openness to experience characteristic, rate of assets output, the size of company and the rate of sales growth. Since the quantity of Durbin-Watson is between the standard intervals 1.5 to 2.5 , one could conclude the independence of the remaining quantities. According to the above table, the calculated meaningful level for the statistic $\mathrm{F}$ is smaller than 0.05 and shows the meaningfulness of regression at level $95 \%$. Therefore, based on the mentioned indicators the model has the needed adequacy.

\subsection{Sixth hypothesis}

There is a meaningful relationship between the managers' personal characteristics and capital structure.

Table 17. Pearson's correlation coefficient between sixth hypothesis variables

\begin{tabular}{|c|c|c|c|c|c|c|c|c|c|}
\hline & Statistic & Extroversion & Agreement & Conscientiousness & Neurosism & $\begin{array}{l}\text { Openness to } \\
\text { experience }\end{array}$ & $\begin{array}{c}\text { Rate of assets } \\
\text { output }\end{array}$ & Size & $\begin{array}{l}\text { Rate of sales } \\
\text { growth }\end{array}$ \\
\hline \multirow{3}{*}{$\begin{array}{l}\text { Capital } \\
\text { structure }\end{array}$} & $\begin{array}{l}\text { Pearson's } \\
\text { coefficient }\end{array}$ & -0.353 & $0.703^{*+}$ & $0.768^{*+*}$ & -0.354 & $0.455^{\star *}$ & $0.754^{* *}$ & $0.347^{* *}$ & $0.576^{* *}$ \\
\hline & $\begin{array}{l}\text { Meaningful } \\
\text { level }\end{array}$ & 0.001 & 0.000 & 0.000 & 0.001 & 0.000 & 0.000 & 0.001 & 0.000 \\
\hline & Number & 85 & 85 & 85 & 85 & 85 & 85 & 85 & 85 \\
\hline
\end{tabular}

According to the above table, since a meaningful level for each of the variables in front of the capital structure is smaller than the error amount 0.05 , so as the result, the null hypothesis is rejected and $\mathrm{H}_{1}$ (research hypothesis) which asserts the existing meaningful relationship between personal characteristics, rate of assets output, size and rate of sales growth with capital structure, is confirmed and the correlation coefficient are $-0.353,0.703,0.768,-0.354,0.455,0.754,0.347$ and 0.576 .

Table 18. Regression coefficients of the sixth hypothesis test

\begin{tabular}{|c|c|c|c|}
\hline \multirow{2}{*}{$\begin{array}{l}\text { Explanatory } \\
\text { variable }\end{array}$} & Dependent variable & \multicolumn{2}{|c|}{ (Capital structure) } \\
\hline & coefficient & Statistic T & P-value \\
\hline Fixed Amount & -0.643 & -2.444 & 0.017 \\
\hline Extroversion & -0.208 & -4.222 & 0.005 \\
\hline Agreement & 0.745 & 10.791 & 0.000 \\
\hline Conscientiousness & 0.816 & 12.622 & 0.000 \\
\hline Neurosism & -0.351 & -5.646 & 0.008 \\
\hline Openness to experience & -0.606 & 8.091 & 0.003 \\
\hline Rate of assets output & 0.456 & 4.617 & 0.000 \\
\hline Amount & 0.006 & 0.485 & 0.629 \\
\hline Rate of sales growth & 0.086 & 2.696 & 0.009 \\
\hline Statistic F & \multicolumn{3}{|c|}{39.788} \\
\hline$P$-value & \multicolumn{3}{|c|}{0.000} \\
\hline $\mathbf{R}^{2}$ & \multicolumn{3}{|c|}{0.807} \\
\hline Adjusted R² & \multicolumn{3}{|c|}{0.787} \\
\hline Durbin-Watson & \multicolumn{3}{|c|}{1.651} \\
\hline
\end{tabular}

According to coefficient column for capital structure the regression equation could be as follows:

$\mathrm{DR}_{\mathrm{it}}=(-0.643)+(-0.208)$ EXT $+(0.745)$ CONS + (0.816) NEUR + (- 0.351) AGREE+ (0.606) OTE + $(0.456)$

$\mathrm{ROA}_{\mathrm{it}}+(0.006) \mathrm{SIZE}_{\mathrm{it}}+(0.086) \mathrm{GR}_{\mathrm{it}}+\varepsilon_{\mathrm{it}}$

In Table 18, a meaningful level of $T$ test which is related to regression coefficient of the studied variables 
(personality characteristics) is shown; this quantity for variables is lower than the acceptable meaningful amount (0.05), therefore the variables are effective in capital structure. Also, the fixed amount has a meaningful level smaller than 0.05 (the acceptable meaningful level) so, it is effective in capital structure. Using the regression coefficient, it can be said that with one unit progression in each independent variable, the dependent variable will improve up to the written coefficient. The regression coefficients revealed that among the managers' personality characteristics, extroversion and Neurosism characteristics have meaningful reverse negative effects on capital structure. Neurosism characteristic with - 0.351 coefficients, have had more reverse effect on capital structure than extroversion characteristic with -0.208 coefficient. In the other hand, agreement, conscientiousness and openness to experience characteristics have meaningful direct positive effects on capital structure. Among them, considering the amount of positive effectiveness, conscientiousness with 0.816 coefficient has had the most effect on capital structure and it is at first place, agreement with 0.745 coefficient in second place and finally, openness to experience with 0.606 coefficient is at third place.

Based on the achieved results, determining coefficient $\left(R^{2}\right)$ for the dependent, capital structure is 0.807 and this quantity shows that 81 percent of capital structure changes could be explained by personality characteristics changes. Since, the amount of Durbin-Watson statistic is between the standard intervals 1.5 to 2.5 , so the independence of remaining quantities can be concluded. According to the above table, the calculated meaningful quantity for this statistic $F$ is smaller than 0.05 , it shows the meaningfulness of regression at $95 \%$ level. Based on the mentioned indicators, this model has the required adequacy.

\section{Conclusion}

What is done as the whole conclusion about the dependent and independent variables, is that there is a relationship between managers' personality characteristics and the capital structure. The results of this study show that the mean of managers' neurosism is lower than the average level and the means of conscientiousness and extroversion components is higher than the average level which is similar to Khanifer et al., results, (2009) but in agreement and openness components the results are opposite to theirs and lower than the average level. Based on the achieved results of the present study that revealed the reverse relationship between extroversion and capital structure, and if it is accepted that generally the extrovert managers have better feelings about their organization and environment, the preference of using the internal resources instead of external resources can be concluded. On the other hand, the reverse relationship between neurosism and capital structure could be interpreted as: since neurosism, according to definition, has alerting influence in group decision-making and this issue takes place through identifying the negative aspects of the made decision, managers have more attention to bankruptcy costs resulting from the use of financial fulcrum in capital structure decisions and as a result, increasing this characteristic, the ratio of debt to capital will decrease. People who have acceptance of experience (openness to experience) can be useful in the professions that have great change and evolution or need remarkable risk and innovation (Khanifer et al., 2009). Since the existence of a meaningful direct relationship between capital structure and managers' openness to experience characteristic was shown in the results, it can be argued that with increase in manager's risk-acceptance (which is a feature of open-to-experience people) it is expected that s/he prefer s/he prefer to use the debts in order to provide the needed funds of company.

\section{References}

Brounen, D., Jong, A. D., \& Koedijk, K. (2006). Capital structure policies in Europe: Survey evidence. Journal of Banking \& Finance, 30(5), 1409-1442.

DeAngelo, H. and DeAngelo, L. and Whited, T. (2011). Capital structure Dynamics and Transitory debt. Journal of Financial Economics. 99(2): 235-261.

Eslami Bidgoli, Gh., and Mazaheri, T. (2010). The Study of Static Parallel and Hierarchical Theories in Identifying The Capital Structure of Companies in Tehran Securities Bourse. Accounting Survey Journal 3:4-21.

Khanifer, H., and Moghimi, S. M. (2010). Recognizing Managers' Personality, The Requirement for Organizational Behavior Management (A Case Study of The Personality Five-Factor Model in Medical Science University, Ghom). Health Management Journal 37: 49-55.

Kordestani, G., and Najafi Omran, M. (2009). A Review on Capital Structure Theories. Accountant Journal, 198 (In Persian).

Lashkari, M., and Mortazi, H.(2002). Financial-Behavioral Theory and Its Effect on the Volume of People Investment in Tehran Securities Bourse. Rahbord, Yas.

Malmendier, U., Tate, G., Yan, J. (2010). Managerial beliefs and corporate financial policies. Unpublished NBER Working paper, No. 15659 .

Mayfield Arnold, E., Rice, E., Flannery, D., and Rotheram-Borus, M.J. (2008). HIV disclosure among adults living with HIV. AIDS Care, 
20, 80-92.

McCrae, R. R., \& Costa, P. T., Jr. (1987). Validation of the five-factor model of personality across instruments and observers. Journal of Personality and Social Psychology, 52, 81-90.

McCrae, R. R., \& Costa, P. T., Jr. (1991). The NEO Personality Inventory: Using the five-factor model in counseling. Journal of Counseling and Development, 69, 367-372.

Myers, S. C. (2001). Capital Structure. The Journal of Economic Perspectives, 15(2), 81-102.

Nasirzadeh, F., and Mostaghiman, A. (2010). Testing Theories of Static Parallel and Hierarchical Capital Structure in the listed Companies in Bourse. Shiraz University Accounting Progressions Journal 59: 133-158.

Ricciardi, V. (2008). The Psychology of Risk: The Behavioral Finance Perspective, Journal of Finance, October, 53:5, pp. 1775-798.

Setayesh, M. H., Kargar Fard Jahromi, M. (2002). The Study of the Effect of Competition in Production Market on the Capital Structure. Experimental Researches of Financial Accounting Quarterly 1:10-23. 